Volume 10 Issue 2 (2021) Pages 143-156

Ta'dib : Jurnal Pendidikan Islam

ISSN: 2528-5092 (Online) 1411-8173 (Print)

https:// ejournal.unisba.ac.id/index.php/tadib/article/view/7895

\title{
TELAAH FILOSOFIS FITRAH MANUSIA DAN ILMU PENGETAHUAN DALAM ISLAM: KARAKTERISTIK, HUBUNGAN ORGANIK, DAN IMPLIKASI KEPENDIDIKAN
}

\author{
Ali Mahmud Ashshiddiqi ${ }^{1 凶}$ \\ ${ }^{1}$ Program Studi Psikologi, Universitas Islam Indonesia \\ DOI: $10.29313 /$ tjpi.v10i2.7895
}

\begin{abstract}
Abstrak
Pembacaan kreatif berdasarkan pandangan-dunia Islam terhadap hakikat fitrah manusia dan ilmu pengetahuan dibutuhkan untuk memperkuat dasar-dasar logika pedagogik bagi praksis pendidikan Islam di tengah tantangan zaman saat ini. Penelitian kepustakaan ini bertujuan menelaah secara filosofis karakteristik fitrah manusia dan ilmu pengetahuan, hubungan organik antara keduanya, dan implikasi kependidikan. Penulis melalui analisa deskriptif menggambarkan karakteristik fitrah manusia dan ilmu pengetahuan, dan melalui analisa sintetik menarik benang merah hubungan organik di antara kedua entitas ini. Secara reflektif, penulis kemudian menganalisa implikasi-implikasi kependidikan Islam. Baik fitrah manusia maupun ilmu pengetahuan, keduanya sama-sama diikat oleh nilai-nilai iman dan ketauhidan serta memiliki dimensi eskatologis. Penulis menyimpulkan bahwa hubungan organik antara fitrah manusia dan ilmu pengetahuan itu bersifat implikatif, persyaratan, ketergantungan kreatif, kesatuan, logis (iman dan amal), serta koheren dan konstruktif. Implikasi-implikasi yang dapat diungkap adalah bahwa pendidikan Islam mengembangkan dan memelihara potensi fitrah, berwawasan tauhid, membentuk kesatuan fungsional khalifah-hamba, bersifat progresif, dan merupakan pendidikan profetik.
\end{abstract}

Kata Kunci: Fitrah; Hubungan Organik; Ilmu Pengetahuan; Implikasi; Pendidikan Islam.

Copyright (c) 2021 Ali Mahmud Ashshiddiqi

$\square$ Corresponding author:

Email Address : ali.ma@uii.ac.id

Received 29/04/2021, Accepted 27/01/2022, Published 28/01/2022 


\section{PENDAHULUAN}

Manusia, sebagai khalifah Allah di muka bumi, memiliki dua anugerah yang sangat istimewa, kebebasan dan ilmu pengetahuan. Kebebasan menjadikan manusia makhluk moral yang bisa diberi sifat baik atau jahat. Dengan ilmu pengetahuan manusia berpotensi untuk mengetahui seluruh tatanan realitas, dari realitas fisik hingga metafisik (Kartanegara, 2007b). Menurut penulis, kedua anugerah ini bisa menjadi malapetaka. Kebebasan yang melampaui batas bisa menimbulkan bencana, dan ilmu pengetahuan tanpa kontrol nilai bisa membahayakan. Kebebasan manusia menjadi istimewa bila sesuai batas, dan ilmu pengetahuan menjadi istimewa bila membangun kehidupan manusia.

Kesadaran tentang hal tersebut penting mengingat tantangan-tantangan filosofis bagi intelektual muslim zaman sekarang. Tantangan paling serius muncul dari positivisme Barat yang tidak mempercayai entitas-entitas metafisik seperti Tuhan sebagai sebab dan sumber bagi alam semesta, dan bahkan menyerang fondasi-fondasi metafisik (Kartanegara, 2007a). Hegemoni positivisme yang menegasikan entitasentitas metafisik semakin terasa, terlebih ketika etika dan moral kehilangan kekuatan kontrol terhadap laju perkembangan ilmu pengetahuan dan teknologi. Ini sesuai pernyataan Muraille (2019) tentang tantangan-tantangan bagi etika inovasi di dunia yang mengglobal dan liberal saat ini. Bahwa konsepsi tradisional etika ditantang oleh dunia global dan ancaman besar teknologi, dan oleh ideologi ekonomi filosofis dan liberal. Jika kemajuan-kemajuan peradaban manusia sudah tidak bisa lagi dikendalikan oleh etika, maka sistem nilai yang berlandaskan ajaran agama maupun norma sosial akan menjadi tidak berdaya mencegah kerusakan di berbagai dimensi kehidupan.

Tidak hanya melanda dunia ilmu pengetahuan, pandangan positivistik turut melahirkan pemikiran-pemikiran pendidikan yang mengusung cita-cita kebebasan yang mengabaikan etika dan moral universal. Menurut Tufekčić (2015) konsep-konsep pendidikan neo-liberal sering mengkaburkan krisis pendidikan dengan pengabaian atas pedoman universal dasar pendidikan. Ini disebabkan penekanan yang begitu kuat terhadap semangat pembebasan individu. Jika benar demikian, sedikit maupun banyak, pendidikan Islam sendiri telah ikut merasakan pengaruh krisis tersebut. Krisis ini berkembang hingga menimbulkan kegalauan bahkan keraguan terhadap dasar-dasar pedoman otentik pendidikan Islam itu sendiri dan kecenderungan terhadap pilihan sikap ideologis yang berpihak pada nilai-nilai di luar ajaran Islam.

Sebagaimana analisa Bakar (2012), pengaruh liberalisme dan neoliberalisme terhadap pendidikan Islam di Indonesia telah tampak pada pandangan terhadap anak didik, orientasi pendidikan, lembaga pendidikan, guru, metode, kompetisi dan komersialisasi. Dekonstruksi pada aspek-aspek ini dapat mengikis eksistensi pendidikan Islam. Sementara secara internal, tantangan yang dihadapi berkaitan dengan kualitas sumber daya manusia, tata kelola, dan pendanaan yang berat. Tantangantantangan ini membutuhkan penguatan basis filosofis, terutama basis aksiologis. Aktualisasi nilai-nilai fundamental dan esensial dari ajaran Islam menjadi penting agar ideologi pendidikan Islam senantiasa terjaga dan menjadi kekuatan pendorong bagi perkembangan pendidikan Islam di atas jatidirinya sendiri tanpa lagi dibayang-bayangi oleh imperialisme paham atau ideologi lain yang tidak sejalan apalagi bertentangan.

Tantangan-tantangan di atas telah lama diingatkan oleh Sardar (1996), bahwa imperialisme epistemologis dari peradaban Barat telah mengabaikan, dan bahkan menyingkirkan, alternatif-alternatif epistemologi lain termasuk epistemologi yang 
berada di jantung pandangan-dunia (world-view) Islam. Hampir semua asumsi dasar dari peradaban Barat modern merupakan antitesa dari prinsip-prinsip Islam. Untuk menghadapi tantangan peradaban modern yang seringkali bertentangan dengan wahyu, umat Islam perlu menghayati kembali tradisi yang hidup atau ajaran-ajaran agama (Nasr, 1983, 1994).

Hidayat (2015) menyatakan bahwa pada dasarnya Islam dan sains adalah sebuah kesatuan. Tanpa diintegrasikan pun sebenarnya keduanya sudah terintegrasi dari asalnya. Jika ada pemisahan antara Islam dan sains, sebagaimana terjadi di dunia Islam, itu disebabkan karena kesalahpahaman terhadap nilai-nilai ajaran Islam yang universal (kaaffah). Penulis mengamati bahwa kajian tentang ilmu pengetahuan dalam perspektif filsafat Islam telah banyak dilakukan dengan beragam pola pendekatan. Upaya ini bertujuan meneguhkan kembali nilai-nilai ideal serta signifikansi perannya dalam kehidupan kontemporer supaya mampu menjawab tantangan zaman. Bagaimana dengan kajian tentang manusia? Tema-tema pembahasan mengenai fitrah maupun konsep manusia menurut Islam juga sudah banyak diangkat di kancah penelitian dan pengkajian. Sejauh ini, menurut penulis, perhatian terhadap hubungan antara kedua entitas tersebut (fitrah manusia dan ilmu pengetahuan) hampir saja terlewatkan, atau masing-masing masih dibahas secara terpisah sebagai satu fokus telaah yang serius. Padahal, untuk menegaskah prinsip-prinsip utama dari ajaran tauhid serta implikasinya bagi pendidikan Islam, hubungan tersebut butuh diungkap. Kekuatan mengikat dari ajaran tauhid terhadap aspek-aspek kehidupan manusia dengan demikian lebih powerful dan impactful.

Upaya yang harus dilakukan oleh umat Islam adalah mengeksplorasi lebih jauh sifat fakultas manusia yang lebih tinggi dan membangkitkan serta memeliharanya dalam proses pendidikan Islam yang otentik (Hassan et al., 2010). Oleh sebab itu, proses pendidikan Islam harus bertumpu pada pemahaman atas karakteristik fitrah manusia yang bersumber dari pandangan-dunia Islam. Otentisitas pendidikan Islam selalu membutuhkan komitmen untuk menjalankan proses pendidikan yang mentaati azasazas ajaran tauhid yang bersemangat pembebasan. Ini merupakan suatu keharusan (necessity), mengingat pendidikan Islam memiliki cakupan antara lain membina dan mengembangkan pendidikan agama yang titik beratnya terletak pada internalisasi nilai iman, Islam dan ihsan dalam pribadi manusia muslim yang berilmu pengetahuan luas (Masduki, 2015).

Penulis sepakat bahwa untuk menyongsong kebangkitan kembali ilmu pengetahuan dan peradaban Islam, perlu penegasan kembali orientasi spiritual (tauhid) dan orientasi humanis sekaligus (Irawan, 2011). Pembacaan secara lebih kreatif terhadap hakikat ilmu dapat memperjelas logika pedagogik yang mendasari praksis pendidikan, karena konsep dan praksis pendidikan berkaitan dengan problem keilmuan (Muslih, 2012). Hal yang sama penting adalah meninjau ulang hakikat fitrah manusia karena posisi sentralnya bagi diskursus filosofis maupun psikologis tentang pendidikan Islam.

\section{METODOLOGI PENELITIAN}

Penulis ingin mengungkap karakteristik fitrah manusia dan ilmu pengetahuan, hubungan organik antara keduanya serta implikasi-implikasi kependidikan Islam. Penelitian ini merupakan penelitian kepustakaan dengan menjadikan penjelasan dalam literatur-literatur bidang filsafat Islam tentang fitrah manusia, ilmu pengetahuan, dan 
pendidikan Islam sebagai obyek utama. Penjelasan literatur diletakkan sebagai basis filosofis primer telaah. Berikutnya, rangkaian metode analisa deskriptif, analisa sintetik, dan analisa reflektif dilakukan untuk memperoleh hasil.

Pertama-tama, penulis menganalisa secara deskriptif fitrah manusia dan ilmu pengetahuan untuk mengungkap karakteristik esensial dan fundamental masingmasing. Karakteristik-karakteristik ini menjadi unsur mendasar untuk memahami lebih lanjut hubungan organik antara fitrah manusia dan ilmu pengetahuan. Secara sintetik analisa penulis berlanjut untuk menemukan hubungan organik yang dimaksud.

Terakhir, penulis secara reflektif memunculkan implikasi-implikasi kependidikan Islam berdasarkan karakteristik fitrah manusia dan ilmu pengetahuan serta hubungan organik yang terjalin diantara keduanya. Implikasi ini secara logis merupakan reaktualisasi elan vital dan makna esensial pendidikan Islam yang memiliki dasar nilai tauhid dan yang berasal dari pandangan-dunia Islam tentang manusia dan ilmu pengetahuan.

Langkah-langkah analisis dalam penelitian ini selanjutnya dapat digambarkan dalam skema proses sebagai berikut:

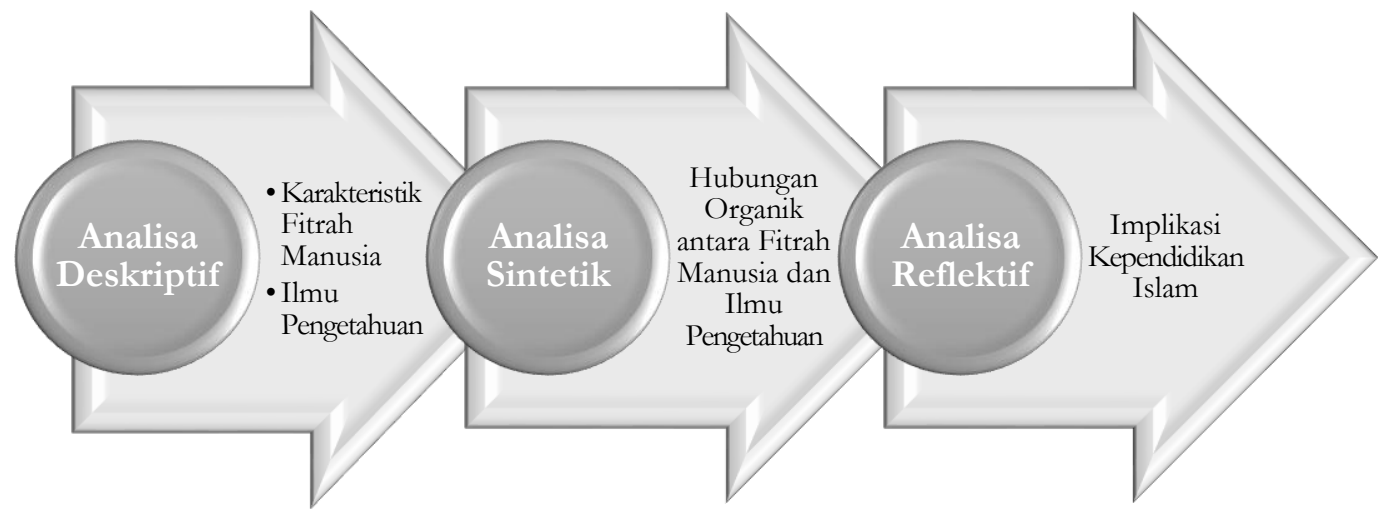

\section{HASIL DAN PEMBAHASAN}

\section{Karakteristik Fitrah Manusia}

Fitrah, dalam pandangan Al Ghazali (Zainuddin, 1991), adalah suatu sifat dasar manusia yang mengandung keistimewaan-keistimewaan: beriman kepada Allah SWT.; kemampuan dan kesediaan untuk menerima kebaikan dan keburukan; dorongan ingin tahu akan hakikat kebenaran; dorongan biologis (syahwat dan insting); serta kekuatan atau dorongan lain yang bisa dibina dan dikembangkan. Ini menunjukkan bahwa iman menjadi pangkal dari fitrah, yang oleh Al Faruqi (1988) dinyatakan pada awalnya sebagai suatu kategori kognitif selain sebagai kategori etika. Iman adalah dasar bagi suatu penafsiran yang rasional atas alam semesta. Iman itu bukan sekedar perasaan, ia memiliki kandungan kognitif (Iqbal, 2016). Iman sejati terfokus pada dua faktor penunjang yang kuat, yaitu kekuasaan berpikir dan respon emosional terhadap ayatayat Qur'aniyah dan ayat-ayat Kauniyyah (Adhim, 1989).

Berdasarkan hal tersebut dapat dipahami bahwa keistimewaan fitrah berpangkal pada keimanan yang memberikan dorongan-dorongan intrinsik dalam diri manusia. Iman, sebagai dasar sikap dan perilaku yang benar, memiliki dimensi rasional kritis yang mendorong rasa ingin mengetahui hakikat kebenaran melalui berpikir tentang ayat-ayat Allah SWT. Meskipun begitu, sikap dan perilaku tersebut bisa salah 
dan buruk, karena adanya dorongan-dorongan negatif dari unsur-unsur lain. Pembinaan dan pengembangan fitrah sangat dibutuhkan, mengingat manusia bersifat terbuka menerima keburukan dan kebaikan.

Mohamed (1997) menjelaskan bahwa selain terkait dengan realitas bawaan manusia, fitrah juga berarti bagi keyakinan nilai-nilai dan sikap dalam kehidupan, pandangan-dunianya dan interaksinya dengan lingkungannya. Hubungan antara sifat dasar bawaan manusia dan kehidupan itu merupakan suatu keharusan, sebab fitrah berarti sesuatu bagi aspek-aspek kehidupan. Aspek-aspek yang menunjukkan eksistensi manusia merupakan implikasi-implikasi yang saling mempengaruhi satu sama lain dan memberi gambaran makna yang utuh tentang fitrah manusia. Implikasi-implikasi tersebut menunjukkan tugas atau kewajiban manusia dan mencakup implikasi metafisis, epistemologis, etis, psikologis, kehendak, dan hukum.

Pertama-tama, secara metafisis sejak lahir manusia membawa kecenderungan untuk mengimani dan menyembah Allah dimana tauhid intrinsik dengan fitrah. Agar manusia mengenali penciptanya dan memahami petunjuk dalam wahyu maka sebagai implikasi epistemologis, Allah mengaruniai kepadanya fakultas-fakultas yang dengannya manusia mampu merasakan dari persepsi inderawi terendah, persepsi rasional, hingga persepsi spiritual tertinggi. Berdasarkan implikasi etis, penyembahan kepada Allah sebagai kecenderungan alami manusia tidak terbatas pada kepercayaan dan ibadah formal, tetapi juga perilaku-perilaku etis yang ditentukan secara ilahiah dalam kehidupan. Tindakan yang benar adalah alamiah bagi manusia dan selaras dengan fitrahnya.

Namun demikian, manusia masih memiliki potensi untuk salah. Meskipun manusia tidak jahat ia tidak kebal terhadap rangsangan jahat atau sumber-sumber kesesatan ekstemal. Ketidakkebalan terhadap kesalahan ini adalah intrinsik pada diri manusia atau merupakan implikasi psikologis dari fitrahnya. Fitrah juga mengandung implikasi kehendak dimana manusia bebas mengaktualisasikan keadaan aslinya dalam keimanan suci dan karakter yang lurus atau menyimpang dari keadaan asli ini. Selanjutnya, kebebasan manusia dalam berkehendak harus diatur dan dipergunakan agar sesuai dengan syariat Islam atau kehendak Tuhan sebagai kerangka kerja, dan selaras dengan fitrahnya.

Berdasarkan karakteristik dan implikasi-implikasi fitrah, maka dapat ditarik kesimpulan-kesimpulan pokok tentang fitrah manusia. Pertama, secara metafisis terdapat dimensi ilahiah berupa sifat-sifat ketuhanan, keimanan, ketundukan dan kepatuhan, yang dimanifestasikan manusia ke dalam peribadatan formal atau sikap dan perilaku etis. Tetapi secara psikologis manusia bisa berbuat salah dan menyalahi sifatsifat dasar alamiahnya karena unsur emosional nafsu dan kehendak bebas. Kedua, agar manusia bisa melaksanakan ketaatan serta memahami setiap petunjuk yang datang dari Allah, manusia dianugerahi fakultas-fakultas epistemologi sehingga ia mampu mencari hakikat kebenaran dan meningkatkan spiritualitasnya. Ketiga, agar manusia bisa selalu menjaga sifat-sifat dasarnya yang baik serta menguasai atau mengendalikan dirinya sendiri diperlukan seperangkat aturan hukum. Faktor eksternal pemeliharaan fitrah berperan penting dalam upaya tersebut.

\section{Akal sebagai Penopang Fitrah}

Akal manusia sesungguhnya mempunyai bermacam-macam arti. Al Ghazali (1990) mengemukakan empat pengertian akal yang bertingkat, sesuai dengan 
perkembangan akal pikiran manusia dan usaha pengembangannya. Akal adalah suatu sifat yang membedakan manusia dari binatang. Akal bersedia menerima berbagai macam ilmu melalui proses pemikiran. Selanjutnya, hakikat akal adalah ilmu pengetahuan yang timbul dari alam wujud dan atau tumbuh pada anak yang mumayyir, yaitu dapat membedakan kemungkinan hal yang mungkin dan kemustahilan hal yang mustahil. Terakhir, hakikat akal adalah puncak kekuatan gharizah (semangat) untuk mengetahui akibat dari segala persoalan dan mencegah hawa nafsu yang mengajak pada kesenangan seketika dan mengendalikannya. Akal pertama dan kedua merupakan "tabiat", sedangkan akal yang ketiga dan keempat adalah "diusahakan".

Pengembangan akal dengan begitu harus mencakup kualitas intelektual dan moral. Al Qurthubi (Jalal, 1988) menjelaskan bahwa akal sesungguhnya tanda kodrati setiap keutamaan, menjadi sumber setiap adab, penopang ad dien (agama) dan tiang dunia. Melalui aktivitas berpikir, manusia dengan akalnya bisa mencapai derajat keimanan yang tidak bisa dihasilkan oleh sekedar amal ibadah biasa. Aktivitas ini adalah sesuatu yang pokok dan kunci bagi seluruh kebaikan, penting bagi perubahan pandangan seorang muslim terhadap dirinya dan kesiapannya untuk perubahan perilaku dan kebiasaan, dan membawa kepada kesadaran tentang hari akhir dan pengetahuan tentang Tuhan (Badri, 1996, 2009; Qardhawy, 1998).

Sampai disini dapat dipahami bahwa akal memiliki kedudukan fungsional sebagai penopang fitrah. Ia merupakan potensi rohani yang dengannya manusia dibedakan dari makhluk lain. Kesatuan aktivitas akal, berpikir dan berdzikir, akan membawa manusia kepada keimanan (tauhid) yang intrinsik pada fitrah. Agar bisa mencapai akhir kehidupan yang baik saat berjumpa dengan Tuhannya, manusia yang semenjak awalnya baik, harus mendayagunakan seluruh karunia yang telah diberikan kepadanya untuk kebaikan.

\section{Karakteristik Ilmu Pengetahuan \\ Sumber Pengetahuan}

Sumber utama pengetahuan di dalam Islam adalah Al Qur'an. Bahkan, sebagai penegasan tauhid, Al Faruqi (1988) mengungkapkan bahwa sumber semua pengetahuan manusia adalah Tuhan, karena Dia-lah yang mengajarkan pada manusia segala sesuatu sehingga ia mengetahui (QS. Al 'Alaq, 96: 5). Bahwa Allah adalah pencipta alam dimana manusia memperoleh pengetahuannya. Obyek pengetahuan adalah pola-pola alam yang merupakan hasil karya Tuhan (QS. Al Hijr, 15: 20; QS. Yunus, 10: 5-6). Allah mengetahuinya secara pasti sebab Dia adalah penciptanya; dan secara pasti pula karena Dia adalah sumber wahyu. Menurut Wan Daud (1997), sebagai wahyu Allah, Al Qur'an merupakan sumber internal yang menunjukkan sumbersumber pengetahuan eksternal, kajian dan orientasi penting yang dapat melengkapi kebenaran wahyu, seperti fenomena alam dan peristiwa historis, metafisis, sosiologis, alami dan eskatologis (QS. Fushshilat, 41: 53).

Al Qur'an tidak hanya menunjukkan tapi juga sangat menekankan pentingnya pengetahuan-pengetahuan empiris tersebut menyentuh atau sampai ke hati dan menghidupkan persepsi batin manusia (Rahman, 1983). Memisahkan pengalaman fisik dari pengalaman batin akan merendahkan kepribadian manusia, mengasingkan manusia, dan akhimya menghancurkan manusia (Sardar, 1989). Penekanan ini bertujuan membangkitkan semangat empiris manusia di zaman yang telah menafikan nilai dari kenyataan yang tampak dalam usaha mencari Tuhan (Iqbal, 2016). 
Pandangan Islam tentang sumber pengetahuan, dengan demikian, holistik dan seimbang. Dengan mengakomodasi sifat-sifat dasar manusia, Islam membuka seluasluasnya dimensi-dimensi pengetahuan yang bisa dijangkau oleh manusia, baik dimensi empiris maupun metafisis, baik pengalaman fisik maupun batin. Islam juga menetapkan secara hirarkis otoritas sumber-sumber pengetahuan manusia. Dengan struktur hirarkis sumber-sumber pengetahuan ini manusia memiliki panduan epistemologis yang mantab dalam membangun dan mengembangkan pengetahuan.

\section{Kesucian dan Kebenaran Pengetahuan}

Pengetahuan yang bersumber pada ayat-ayat Qur'aniyah dan ayat-ayat Kauniyah mengimplikasikan beberapa karakteristik penting terkait kesucian dan kebenaran. Gagasan atau wawasan tentang Yang Maha Suci merupakan titik sentral dari teori tentang pengetahuan menurut Islam. Tujuan pengetahuan tidak lain adalah kesadaran mengenai Yang Maha Suci yang juga harus menyertai dan merembesi setiap tahap proses perolehan pengetahuan. Allah tidak saja berada pada awal proses pengetahuan tetapi juga berada pada akhirnya, menyertai dan memberkati keseluruhan proses tersebut (Qadir, 1992). Kehadiran Allah dalam proses pengetahuan manusia menegaskan bahwa pengetahuan itu pada hakikatnya adalah suci. Kesucian inilah yang seharusnya dijadikan rambu-rambu oleh manusia dalam setiap upaya memperoleh dan memanfaatkan pengetahuan.

Berkaitan dengan kebenaran, menurut Al Faruqi (1988), terdapat tiga prinsip yang mendasari semua pengetahuan Islam, yaitu teori kesatuan kebenaran yang merupakan identitas hukum-hukum alam (sunnatullab) yang tetap dan tidak berubah. Bahwa berdasarkan wahyu manusia tidak boleh membuat klaim yang bertentangan dengan realitas. Demikian pula tidak ada kontradiksi, perbedaan atau variasi antara nalar dan wahyu. Terakhir, diperlukan sikap kritis dan terbuka terhadap semua klaim manusia disertai pencarian aktif terhadap hukum-hukum alam yang tidak mengenal batas akhir. Apabila terjadi kesenjangan antara ayat-ayat suci Al Qur'an dengan kenyataan-kenyataan empiris, maka secara hakiki kebenaran ilmiah identik dengan kebenaran firman Allah karena gejala alam sebagai obyek ilmu adalah gejala atau manifestasi Allah (Muntasir, 1985).

Hubungan antara pengetahuan dan kebenaran tersebut mendorong dinamika perkembangan pengetahuan manusia sesuai dengan dorongan murni fitrahnya dalam menemukan kebenaran hakiki. Hubungan ini sekaligus juga memberikan kontrol bagi manusia agar memeriksa derajat kebenaran dari pengetahuan-pengetahuan yang di perolehnya. Ini menjadi bukti bahwa Islam memiliki kepedulian yang sangat besar terhadap kebutuhan epistemologis manusia di tengah banyaknya kemungkinan pengetahuan manusia bisa salah dan berdampak buruk bagi kehidupannya.

\section{Fungsi dan Kemanfaatan Ilmu Pengetahuan}

Allah menjunjung tinggi ilmu pengetahuan dan menekankannya kepada manusia karena ia merupakan jembatan penghubung dan media pengenalan manusia terhadap dunia dan penciptanya. Pengetahuan, dari perspektif filsafat Al Quran, memberikan pemahaman tentang kesadaran diri manusia, posisi manusia di alam semesta, dan penyelidikan tentang hakikat pokok dari realitas (QS. Al Baqarah, 2: 3034) (Sarwar, 1994). Ilmu pengetahuan berfungsi untuk mengetahui kebenaran ilmiah maupun wahyu, menjelaskan ajaran akidah Islam, menguasai alam guna meningkatkan 
kesejahteraan dan kebahagiaan umat manusia, dan meningkatkan kebudayaan dan peradaban Islam (Yunus, 1999). Ilmu menempati posisi yang istimewa dan menjadi bagian yang pokok dalam bangunan religiusitas Islam, dimana ia menjadi cara yang utama bagi penyelamatan jiwa dan pencapaian kebahagiaan serta kesejahteraan manusia dalam kehidupan dunia dan akhirat (Bakar, 2010).

Fungsionalitas ilmu pengetahuan terhadap keimanan, peribadatan, dan kebaikan hidup manusia menjadi kriteria utama bagi ilmu yang bermanfaat dan menandai kesuciannya. Menurut Ghulsyani (1996), ilmu hanya berguna dan bernilai jika dijadikan alat untuk mendapatkan pengetahuan tentang Allah, keridhaan dan kedekatan kepada-Nya. Seluruh ilmu merupakan alat utama mendekatkan diri kepada Allah, dan oleh sebab itu ilmu suci meskipun kesucian ini tidak intrinsik. Bahwa ilmu dikatakan bermanfaat dan suci bila mempertebal iman dan ketakwaan, menumbuhkan daya kreatifitas dan produktivitas manusia sebagai pelaksana amanat Tuhan, dan begitu pula sebaliknya. Karena kesuciannya tersebut maka ilmu tidak boleh disalahgunakan atau dipelajari hanya demi ilmu itu sendiri, tetapi untuk mendapatkan keridhaan Allah (Butt, 1996; Husain \& Ashraf, 1994).

Manifestasi dari ilmu yang bermanfaat adalah amal saleh. Ilmu yang bermanfaat tentu saja adalah ilmu yang benar, yang sesuai dengan atau secara tepat mewakili hukum-hukum Allah (Madjid, 1993). Selanjutnya, amal saleh harus dipandang dalam kerangka ajaran Islam, yakni sebagai perwujudan dari kesatuan fungsional khalifah dan hamba (Asy'arie, 2003). Fungsi dan kemanfaatan ilmu pengetahuan tidak dapat dilepaskan dari peran utama manusia di muka bumi dan kewajibannya terhadap hukum-hukum ketetapan Allah. Muntasir (1985) mengungkapkan bahwa posisi ilmu dapat dilihat dari sudut pandang konsekuensi manusia sebagai khalifah, manusia sebagai hamba, dan sunnatullah. Sebagai khalifah, manusia harus memahami apa yang ada di bumi. Sedangkan sebagai hamba, manusia harus mengabdi pada Allah dan menjadikan itu sebagai satu-satunya aktivitas yang utama dan mendasar. Pengabdian manusia membutuhkan pemahaman tentang konteks hubungan antar komponenkomponen yang membangun alam raya ini, dan tentang liku-liku dan hakikat setiap komponen tersebut. Manusia, dari sudut pandang sunnatullah, wajib memperjelas apa dan bagaimana komponen-komponen itu dalam kerangka hakekat dirinya sebagai khalifah dan pengabdi.

\section{Hubungan Organik Fitrah Manusia dengan Ilmu Pengetahuan}

Berdasarkan pemahaman-pemahaman fundamental-filosofis mengenai karakteristik fitrah dan ilmu pengetahuan, maka sisi-sisi hubungan organik antara keduanya dapat dijelaskan sebagai berikut:

Pertama, akal sebagai pelengkap fitrah dan tanda kesempumaan manusia merupakan syarat bagi potensi manusia untuk berilmu dan karenanya, ia melaksanakan tugas-tugas kekhalifahan. Potensi ini merupakan ketetapan Allah atas diri manusia sebagai subyek tahu. Hubungan antara potensi fitrah dan ilmu pengetahuan dalam hal cara manusia berilmu pengetahuan melalui akalnya dengan demikian menjadi hubungan yang implikatif sifatnya.

Kedua, aktivitas akal dalam bentuk berpikir atau menalar yang esensinya bersifat agamawi serta melekat pada potensi fitrah, merupakan media pembangun kerangka landasan epistemologi suatu disiplin ilmu. Sehingga potensi akal beserta aktivitas dinamisnya menjadi syarat bagi berdiri dan berkembangnya ilmu pengetahuan. Maka 
antara akal sebagai pelengkap fitrah dan ilmu pengetahuan yang diusahakan pembentukan dan pengembangannya oleh manusia terdapat hubungan persyaratan yang harus ada.

Ketiga, ilmu pengetahuan merupakan wujud kemampuan sekaligus kebutuhan manusia yang tersusun dan berkembang dari rasa ingin tahu yang berpangkal pada fitrah. Kemampuan dan kebutuhan manusia kepada ilmu pengetahuan adalah inheren dalam hidup manusia, yaitu dalam hubungan kreatifnya dengan alam; dan inheren dengan hidup manusia untuk pemecahan masalah-masalah hidupnya. Dalam konteks ini, hubungan fitrah manusia dengan ilmu pengetahuan dapat dilihat sebagai hubungan ketergantungan yang kreatif.

Keempat, ilmu pengetahuan merupakan ciri dari manusia dan penjelas bagi eksistensinya, yang tidak bebas nilai, dan memiliki fungsi sosial dalam kehidupan manusia. Ini disebabkan ilmu pengetahuan berada dalam kerangka pengalaman manusia secara total. Keduanya (ilmu pengetahuan dan manusia) merupakan tanda pengejawantahan Dzat Allah yang secara prinsipil diikat oleh pandangan tauhid, bahwa Allah-lah satu-satunya surnber dari mana ilmu pengetahuan dan manusia berasal. Ilmu pengetahuan sebagai ciri manusia dan fitrah manusia itu sendiri berada dalam hubungan kesatuan atau ikatan tauhid.

Kelima, keimanan tauhid yang secara metafisis berakar pada fitrah harus melahirkan dukungan terhadap sistem ilmu pengetahuan Islami dan pemeliharaan tata nilai yang benar dalam strukturnya. Keharusan ini didasari oleh adanya kaitan erat antara konsep epistemologi dengan konsep dienul Islam yang menciptakan ikatan organik antara esensi tauhid, bentuk ritual wajib dan ekspresi manusia berbentuk ilmu pengetahuan, disamping predikat rahmatan lil 'alamin yang disandang setiap muslim yang beriman tauhid. Fitrah manusia yang mengandung dimensi metafisis tauhid, etis dan epistemologis, menjadi dasar berpijak bagi pembentukan dan pengembangan ilmu pengetahuan yang islami. Sehingga hubungan antara fitrah manusia dengan ilmu pengetahuan Islami merupakan hubungan logis antara iman dan amal.

Keenam, kesadaran tauhid melahirkan konsekuensi penting pencarian obyektivitas dalam upaya intelektual atau keadilan di wilayah pengetahuan, sehingga berimplikasi positif bagi dunia ilmu pengetahuan dan kehidupan. Objektivitas tersebut berakar pada fitrah manusia, sah dan dianjurkan, serta mempunyai signifikansi religius yang besar karena berkaitan erat dengan kesadaran tauhid. Objektivitas merupakan sifat manusiawi dan sekaligus kualitas ilahiah yang termanifestasi secara lahiriah oleh manusia sebagai pembawa citra ketuhanan yang terkandung dalam fitrahnya. Berdasarkan pada obyektivitas ini, maka hubungan daya fitrah untuk menemukan dan menegakkan kebenaran obyektif dari sudut pandang tauhid dengan tuntutan objektivitas di dunia ilmu pengetahuan adalah hubungan yang koheren dan konstruktif, bersesuaian dan membangun.

Hubungan-hubungan tersebut didukung oleh pernyataan Sardar (1989) bahwa pengetahuan dalam konsep epistemologi Islam tidak terpisah dengan manusia, alam, dan nilai-nilai. Manusia dan pengetahuan merupakan suatu kesatuan, dimana pengetahuan dikaitkan dengan fungsi sosial manusia dan dipandang sebagai ciri manusia yang mampu menguasai kekuatan alam dalam batas-batas tertentu. Syari'ati (1992) juga berpandangan bahwa Islam, dengan prinsip tauhidnya, menciptakan hubungan dasar dan ikatan eksistensial antara hakikat kemanusiaan dan realitas materi, dengan menyatakan bahwa manusia dan alam sama-sama sebagai tanda 
pengejawantahan Dzat Yang Maha Tinggi. Konsep epistemologi Islam, maka dari itu, tidak terlepas dari konsep dienul Islam yang menyatukan secara-organik esensi tauhid, bentuk ritual wajib, dan ekspresi manusia yang berupa ilmu pengetahuan (Zubair, 1994). Hubungan organik antara fitrah manusia dan ilmu pengetahuan menjadi apa yang disebut Nasr (1994) sebagai gambaran otentik dari Kebijaksanaan dan KehendakNya, yaitu sebuah gambaran tentang kaitan antara segala sesuatu, yang harus diketahui selain tentang ke-Esaan Allah.

\section{Implikasi Paradigmatik bagi Pendidikan Islam}

Hubungan organik antara fitrah dan ilmu pengetahuan memunculkan implikasi-implikasi paradigmatik bagi pendidikan Islam. Implikasi-implikasi ini dilandasi setidaknya tiga asumsi dasar. Bahwa aktualisasi dan perkembangan fitrah manusia tidak bisa mengabaikan peran-peran pembinaan dimana yang paling utama adalah pendidikan. Selanjutnya, ilmu pengetahuan dalam pandangan Islam memiliki arti yang sangat besar bagi kehidupan. Proses pendidikan pun tidak bisa dipisahkan dari upaya manusia membangun dan mengembangkan ilmu pengetahuan. Apabila Islam memiliki pandangan khusus dan unik tentang potensi dasar manusia dan ilmu pengetahuan, maka pendidikan yang bertugas membina dan mengembangkan keduanya juga harus dilandasai oleh nilai-nilai yang lahir dari pandangan-dunia yang sama. Bagaimana kemudian pendidikan Islam itu menjalankan fungsi-fungsi esensialnya pada akhirnya juga tidak boleh tercerabut dari akar pemahaman tentang fitrah manusia dan ilmu pengetahuan yang secara hakiki dan sesuai dengan nilai-nilai prinsipil yang mendasari keduanya adalah saling berhubungan

Pertama, pendidikan Islam mengembangkan dan memelihara potensi fitrah. Menurut Al Jamali (1988), tujuan akhir dari semua pendidikan yang sehat dan berguna ialah mengarahkan manusia kepada kehidupan yang baik dan meningkatkan martabat kemanusiaannya dan menyelamatkan manusia dari keburukan hawa nafsu dan lingkungan yang rusak. Secara operasional pendidikan Islam menumbuhkan dan membina keimanan, penggunaan rasio (akal) dan analisa, akhlak dan amal shalih. Selain itu pendidikan Islam menjaga dari dan memperbaiki kesesatan dan kebatilan, kerusakan jasmani, gangguan kesehatan, kerusakan hubungan sosial, penyakit moral dan bahaya dari luar. Implikasi ini muncul

Kedua, pendidikan Islam berwawasan tauhid. Al Jamali (1986) dan Ramayulis (1994) menjelaskan bahwa tujuan pendidikan berdasarkan Al Qur'an meliputi empat pengenalan, yaitu: mengenalkan manusia tentang peranannya di antara sesama makhluk tanggungjawabnya di dalam hidup ini, mengenalkan manusia tentang interaksi sosial dan tanggung jawabnya dalam taat hidup bermasyarakat, mengenalkan manusia tentang alam ini dan mengajak untuk memahami hikmah serta membukakan kemungkinan pemanfaatannya, dan mengenalkan manusia tentang Pencipta alam ini (Allah) dan memerintahkan kepada mereka untuk beribadah kepada-Nya. Tiga tujuan yang pertama merupakan sarana untuk mencapai tujuan yang terakhir dan utama, yakni ma'rifatullah dan bertakwa kepada-Nya. Sehingga yang menjadi kurikulum inti (intra kurikulum) pendidikan Islam adalah tauhid yang harus menjadi unsur pokok dan permanen. Kurikulum inti selanjutnya ialah tentang perintah membaca ayat-ayat Allah yang berjiwa tauhid, baik Qur'aniyyah, diri manusia, maupun alam semesta.

Pendidikan Islam memiliki wawasan tauhid dalam memandang manusia, alam, dan Tuhan. Ketiga-tiganya dipandang bukan sebagai sesuatu yang terpisah melainkan 
suatu kesatuan yang saling mempengaruhi. Wawasan tauhid dapat menciptakan nilainilai positif dan konstruktif bagi kemajuan di segala bidang dan dimensi kehidupan karena merupakan inti keimanan dan sekaligus pondasi seluruh tatanan kehidupan umat Islam.

Ketiga, pendidikan Islam membentuk kesatuan fungsional khalifah-hamba. Abdullah (1994) menjelaskan bahwa konsep fitrah menuntut agar pendidikan Islam harus bertujuan mengarahkan terjalinnya ikatan yang kuat seorang manusia dengan Allah. Pendidikan Islam secara umum bertujuan membentuk kepribadian sebagai khalifah Allah yang beriman kepada Allah dan tunduk patuh secara total kepada-Nya. Pendidikan Islam dengan demikian harus dapat mendorong manusia mencapai ma'rifatulah sehingga mampu mengabdi secara total, dan mendorong manusia untuk memahami cara-cara Allah memelihara alam ini serta memanfaatkan segala anugerah ciptaan Allah untuk menjaga dan menguatkan keimanan (Husain \& Ashraf, 1994).

Keempat, pendidikan Islam bersifat progresif. Progresivitas pendidikan Islam tidak sama dengan semangat progresivisme Barat yang menolak otorianisme dan absolutisme dalam segala bentuk, termasuk agama, dan terlalu mempercayai kekuatan alamiah manusia dalam berpikir dan berpengalaman (Barnadib, 1997; Syams, 1986; Zuhairini, 1995). Progresivitas pendidikan Islam didasarkan pada nilai-nilai absolut wahyu yang bersifat membimbing pikiran/kecerdasan dan kemampuan dasar untuk tumbuh dan berkembang. Dengan nilai-nilai ini proses kependidikan lslam berlangsung secara konstan ke arah tujuan yang tidak berubah-ubah (Arifin, 1993), karena adanya sumber dan kerangka konsepsi yang juga mutlak dan tetap. Quthb (1990) juga menegaskan bahwa secara esensial konsep Islam tidak berkembang, tetapi manusialah yang berkembang dalam kerangka konsep tersebut dan meningkat di dalam memahami dan menanggapinya. Manusia akan tetap berkembang dan meningkat, tumbuh dan maju, sedang kerangka ini akan selalu mencakupnya dan akan selalu membimbingnya; sebab sumber yang menciptakan konsep ini adalah sumber yang juga menciptakan manusia.

Kelima, pendidikan Islam adalah pendidikan profetik. Berdasarkan penjelasan Kuntowijoyo (2017), istilah "profetik" menekankan pada arti usaha mengubah keadaan bukan semata-mata demi perubahan itu sendiri atau untuk tujuan penyesuaianpenyesuaian, melainkan mengubah berdasarkan cita-cita etik dan profetik tertentu. Cita-cita etik dan profetik ini diderivasikan dari misi historis Islam sebagaimana terkandung dalam Surat Ali Imran ayat 110, yang meliputi: humanisasi/emansipasi, karena ada gejala obyektivikasi teknologi atau reduksi terhadap kepribadian manusia secara parsial; liberasi/pembebasan dari kemiskinan, teknologi dan ekonomi; dan transendensi, yaitu menambahkan dimensi transendental dalam kebudayaan manusia. Proyeksi cita-cita profetik dari pendidikan Islam selanjutnya bisa dimaknai sebagai: humanisasi, yaitu menjaga nilai dan martabat manusia sebagai makhluk mulia serta memelihara keutuhan keseimbangan kepribadiannya; liberasi, yaitu memberikan wawasan dan ilmu pengetahuan yang memadai kepada peserta didik untuk melepaskan diri dari belenggu kesulitan-kesulitan hidup; dan transendensi, yaitu pembentukan hubungan yang erat antara peserta didik dengan dimensi-dimensi transendental dalam arti kesadaran terhadap nilai-nilai spiritual dari ajaran tauhid. 


\section{KESIMPULAN}

Baik fitrah manusia maupun ilmu pengetahuan, keduanya sama-sama diikat oleh karakteristik iman dan tauhid serta memiliki dimensi eskatologis. Secara filosofis ada hubungan organik antara fitrah manusia dan imu pengetahuan berdasarkan karakteristik esensial masing-masing. Hubungan ini bersifat implikatif, persyaratan, ketergantungan kreatif, kesatuan, logis (iman dan amal), serta koheren dan konstruktif. Hubungan itu mengandung sejumlah implikasi kependidikan yang penting untuk menegaskan kembali paradigma pendidikan Islam yang berakar kuat pada pandangandunia Islam. Bahwa pendidikan Islam itu berorientasi pada pengembangan dan pemeliharaan fitrah manusia dan memiliki wawasan tauhid, membangun karakter kesatuan fungsional khalifah-hamba, serta bersifat progresif atas dasar cita-cita profetik sebagaimana misi historis Islam.

Hasil penelitian ini bisa menjadi pijakan filosofis bagi pendidikan Islam untuk menuju cita-citanya yang searah dengan tujuan ajaran Islam itu sendiri. Karena filsafat pendidikan Islam harus berorientasi pada tujuan penciptaan manusia dan tujuan risalah Islam (Mustaghfiroh, 2015). Sehingga aktualisasi peran pendidikan Islam di kalangan umat Islam menjadi salah satu manifestasi cita-cita umat Islam untuk melestarikan, mentransformasikan, dan menginternalisasikan nilai-nilai Islam kepada generasi penerus (May, 2015).

Mujib (2015) juga menyatakan bahwa pendidikan Islam menjadi bermakna bagi kelangsungan hidup manusia ketika proses transformasi dan internalisasinya melibatkan aspek-aspek spiritual seperti makna, nilai, transenden, dan keterhubungan bakal menjadi apa nantinya. Aspek-aspek ini akan menunjukkan pembentukan manusia yang hakiki yang menyentuh sisi terdalam dalam kebutuhan manusia kebahagiaan dan kesejahteraan psikologis. Tulisan ini memberi petunjuk tentang aspek-aspek spiritual dalam proses transformasi dan internalisasi pendidikan Islam. Dengan mempertimbangkan implementasi aspek-aspek psiko-spiritual, logika pedagogikpsikologis yang terkandung di dalam fitrah manusia, ilmu pengetahuan, dan atau hubungan antar keduanya menarik untuk diteliti lebih lanjut. Implikasi-implikasi psikologis perlu diungkap lebih mendalam dan terfokus, dalam rangka menggali basisbasis psikologis bagi pendidikan Islam.

\section{DAFTAR PUSTAKA}

Abdullah, A. S. . (1994). Teori-teori pendidikan dalam Al Qur'an (M. Arifin \& Zainuddin, Penterjemah). PT. Rineka Cipta.

Adhim, A. A. (1989). Epistemologi dan aksiologi ilmu: Perspektif Al Qur 'an (A. M. Hakim, Penterjemah). PT. Remaja Rosdakarya.

Al Faruqi, I. R. (1988). Taubid (R. Astuti, Penterjemah). Penerbit Pustaka.

Al Ghazali, I. (1990). Ibya' ulumuddin (Jilid I) (H.M. Zuhri, Penterjemah). Asy Syifa.

Al Jamali, M. F. (1986). Filsafat pendidikan dalam Al Qur 'an (J. Al Falasany, Penterjemah). Bina Ilmu.

Al Jamali, M. F. (1988). Menerobos krisis pendidikan dunia Islam (R. Astuti, Penterjemah). Golden Trayon Press.

Arifin, M. (1993). Filsafat pendidikan Islam. Bumi Aksara.

Asy'arie, M. (2003). Reformulasi filosofis pendidikan Islam. Dalam H. Latief (Ed.), Islam dan pengembangan disiplin ilmu; Sebuah transformasi nilai (pp. 23-35). LPPI UMY.

Badri, M. (1996). Tafakur: Perspektif psikologi Islami (U.S. Husnan, Penterjemah). PT. 
Remaja Rosdakarya.

Badri, M. (2009). Human nature in secular psychology: An Islamic critique. In A. Haque \& Y. Mohamed (Eds.), Psychology of personality, Islamic perspectives (pp. 3960). Cengage Learning Asia Pte Ltd.

Bakar, M. Y. A. 2012. Pengaruh paham liberalisme dan neoliberalisme terhadap pendidikan Islam di Indonesia. Tsaqafah, 8(1), 135-160. https://doi.org/10.21111/tsaqafah.v8i1.22

Bakar, O. (2010). Taubid dan sains; Perspektif Islam tentang agama dan sains (Y. Liputo, Penterjemah). Pustaka Hidayah.

Barnadib, I. (1997). Filsafat pendidikan; Sistem dan metode. Andi Offset.

Butt, N. (1996). Sains dan masyarakat Islam (M. Hilmy, Penterjemah). Pustaka Hidayah.

Ghulsyani, M. (1996). Filsafat sains menurut Al-Qur 'an (A. Effendi, Penterjemah). Mizan Pustaka.

Hassan, A., Suhid, A., Abiddin, N. Z., Ismail, H., \& Hussin, H. (2010). The role of Islamic philosophy of education in aspiring holistic learning. Procedia - Social and Behavioral Sciences, 5, 2113-2118. https://doi.org/10.1016/j.sbspro.2010.07.423

Hidayat, F. (2015). Pengembangan paradigma integrasi ilmu: Harmonisasi Islam dan sains dalam pendidikan. Jurnal Pendidikan Islam, IV(2), 299-318. https://doi.org/10.14421/jpi.2015.42.299-318

Husain, S. S., \& Ashraf, S. A. (1994). Menyongsong keruntuban pendidikan Islam (R. Astuti, Penterjemah). Gema Risalah Press.

Iqbal, M. (2016). Rekonstruksi pemikiran religius dalam Islam (Hawasi \& M. Kazhim, Penterjemah). Mizan.

Irawan, B. (2011). Urgensi tauhid dalam membangun epistemologi Islam. TS AQAFAH, 7(2), 273-298. https://doi.org/10.21111/tsaqafah.v7i2.3

Jalal, A. F. (1988). Asas-asas pendidikan Islam (H.N. Ali, Penterjemah). C.V. Diponegoro. Kartanegara, M. (2007a). Mengislamkan nalar: Sebuah respons terhadap modernitas. Erlangga.

Kartanegara, M. (2007b). Nalar religius: Menyelami hakikat Tuhan, alam, dan manusia. Erlangga.

Kuntowijoyo. (2017). Paradigma lslam: Interpretasi untuk aksi. Penerbit Tiara Wacana.

Madjid, N. (1993). Pandangan dunia Al Qur'an. Dalam S. Ma'arif \& S. Tuhuleley (Eds.), Al Qur'an dan tantangan modernitas (pp. 3-10). SIPRES.

Masduki, M. (2015). Pendidikan Islam dan kemajuan sains: Historisitas pendidikan Islam yang mencerahkan. Jurnal Pendidikan Islam, 4(2), 261-275. https://doi.org/10.14421/jpi.2015.42.261-275

May, A. (2015). Melacak peranan tujuan pendidikan dalam perspektif Islam. TS AQAFAH, 11(2), 209-222. https://doi.org/10.21111/tsaqafah.v11i2.266

Mohamed, Y. (1997). Insan yang suci (Konsep fitrah dalam Islam) (M. Abadi, Penterjemah). Mizan.

Mujib, A. (2015). Implementasi psiko-spiritual dalam pendidikan Islam. Madania, 19(2), 195-206. https://doi.org/http://dx.doi.org/10.29300/madania.v19i2.38

Muntasir, S. (1985). Mencari evidensi Islam, analisa awal sistem filsafat, strategi dan metodologi pendidikan Islam. Rajawali.

Muraille, E. (2019). Ethical control of innovation in a globalized and liberal world: Is good science still science? Endeavour, 43(4), 1-14. https://doi.org/10.1016/j.endeavour.2020.100709 
Muslih, M. (2012). Problem keilmuan kontemporer dan pengaruhnya terhadap dunia pendidikan. TSAQAFAH, $27-50$. https://doi.org/10.21111/tsaqafah.v8i1.15

Mustaghfiroh, H. (2015). Rekonstruksi filsafat pendidikan Islam (Mengembalikan tujuan pendidikan Islam berbasis tujuan penciptaan dan tujuan risalah). Edukasia : Jurnal Penelitian Pendidikan Islam, 10(1), 89-104. https://doi.org/10.21043/edukasia.v10i1.786

Nasr, S. H. (1983). Islam dan nestapa manusia modern (A. Mahyuddin, Penterjemah). Penerbit Pustaka.

Nasr, S. H. (1994). Menjelajah dunia modern; Bimbingan untuk kaum muda muslim (H. Tarekat, Penterjemah). Penerbit Mizan.

Qadir, C. A. (1992). Filsafat dan ilmu pengetahuan dalam Islam (H. Basari, Penterjemah). Penerbit Obor.

Qardhawy, Y. (1998). Al Qur'an berbicara tenlang akal dan ilmu pengetahuan (A.H. Al Kattam, I. Salim, \& M.H. Sochimien, Penterjemah). Gema Insani Press.

Quthb, S. (1990). Karakteristik konsepsi Islam (Muzakkir, Penterjemah). Penerbit Pustaka.

Rahman, F. (1983). Tema pokok Al Quran (A. Mahyuddin, Penterjemah). Penerbit Pustaka.

Ramayulis. (1994). Ilmu pendidikan Islam. Kalam Mulia.

Sardar, Z. (1989). Sains, teknologi dan pembangunan di dunia Islam (R. Astuti, Penterjemah), Penerbit Pustaka.

Sardar, Z. (1996). Jihad intelektual: Merumuskan parameter-parameter sains Islam (A.E. Priyono, Penterjemah). Risalah Gusti.

Sarwar, H. G. (1994). Filsafat Al Qur'an (Z. Muhtadin, Penterjemah). Raja Grafindo Persada.

Syams, M. N. (1986). Filsafat pendidikan dan dasar filsafat pendidikan. Usaha Nasional.

Syari'ati, A. (1992). Humanisme antara Islam dan maz̧ab Barat (A. Muhammad, Penterjemah). Pustaka Hidayah.

Tufekčić, A. (2015). Reception of critical educational science and the contemporary educational crisis. Procedia - Social and Behavioral Sciences, 174, 414-419. https://doi.org/10.1016/j.sbspro.2015.01.683

Wan Daud, W. M. N. (1997). Konsep pengetahuan dalam Islam (Munir, Penterjemah). Penerbit Pustaka.

Yunus, H. A. (1999). Filsafat pendidikan. Citra Sarana Grafika.

Zainuddin. (1991). Seluk beluk pendidikan dari Al Ghazali. Bumi Aksara.

Zubair, A. C. (1994). Tata nilai dalam epistemologi Islam. Al Jami 'Ah, 57, 87-92.

Zuhairini. (1995). Filsafatpendidikan Islam. Bumi Aksara. 